\title{
IMPORTANCE OF BEEF PRODUCTION IN SERBIA ${ }^{1}$
}

\author{
B. Miščević, S. Aleksić, S. Josipović, V. Pantelić, T. Smiljaković, Dušica Ostojić2
}

Content: Problems relating to importance of production of beef in our country, current condition and possibilities of improvement are main topics of this review paper. Also, importance of production of beef from the aspect of domestic needs and possibilities for export to markets of European Union which would free our economy and country in general of unnecessary import of meat of suspicious quality and alleviate the standard of living to higher level are issues discussed in this paper. More intensive use of experiences obtained from scientific work and experts in the field of cattle breeding as well as development of new breeding methods would solve the problem of improvement of milk and meat production. Use of knowledge of developed countries and good breeding programmes could in very short time give positive results and with much success planned production of beef, which was at very low level recently, could be realized.

Key words: cattle, young cattle, meat, breeding programme

\section{Introduction}

Cattle breeding is most important branch of livestock production. In total livestock production cattle production participates with $45 \%$. The highest production of milk and meat are in cattle production. These products are used for nutrition of population and part (meat and cheeses) are prepared for export.

Within cattle production raw materials are provided for processing industry (dairy plants and slaughter houses). This production is based on use of plant feeds witch no other species of domestic animals could utilize in such efficient way as cattle (Miščević et al. 2003, Lazarević et al. 2001, Lazarević et al.2005).

In the last decade in livestock production in our country negative tendencies are present, low level expressed through natural and financial indicators of production. Livestock production in the Republic of Serbia in the period from 1985. is in stagnation followed by decrease of average 1-2\% annually. Registered decrease relates to number of heads of livestock and total volume of production. Decrease of supply on market is caused by situation on the market, lack of stability and often even chaotic conditions in livestock production in general. Extremely difficult production conditions as well as lack of long term policy of development are present and this is having negative effect on livestock production in general.

Considering current situation on the market of live livestock, meat and milk, as well as fact that number of heads of livestock has been reduced to such level that future production and supply of domestic market and potential export are under serious threat, it is necessary to address the problems of livestock production on all levels.

\section{Current condition in cattle breeding}

In our country approx. 700.000 households are engaged in livestock production or $58 \%$, cattle breeding is organized on over 500.000 households or 3,62 heads in average per household which is good basis for organization of serious production for domestic market and for export. In Republic of Serbia 6,3\% of cattle are owned by agricultural firms or cooperatives and $93 \%$ are on private farms.

Current condition on the livestock, meat and milk market as well as the fact that number of heads of livestock is permanently decreasing, future production, supply of the market and potential export can be seriously endangered. It is necessary to constantly point out the importance of livestock production as a branch of agriculture for its general development and find out the ways to stop further decline of production in this field similar to the way this is done in developed countries (Aass 1996, Chauhan 1986, Dikeman 1994).

In the preceding year livestock production has entered with numerous unsolved problems from previous period. Trends relating to number of heads of livestock, production of meat and milk, unused

1 Review paper - Pregledni rad, supported by the Ministry of Science and Environment Protection, Project no. TR6887B - Rad je finansiran od strane Ministarstva za nauku i zaštitu životne sredine Projektom broj: TR6887B

2 Dr Branislav Miščević, scientific counselor, Dr Stevica Aleksić, scientific counselor, Mr Slavko Josipović, research assistant, Mr Vlada Pantelić, research assistant, Grad.eng.Dušica Ostojić, research trainee, Institute for Animal Husbandry, Belgrade-Zemun. 
capacities and especially export of live heads of livestock and animal products were negative. Of 9,975 $\mathrm{t}$ of beef approved by EU approx. 15 times less has been exported to Italy and Greece. The opportunity to realize

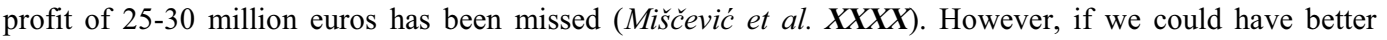
organization livestock breeders, slaughterhouses and commercial firms would have to work very hard to return to markets where we used to be present with our products or conquer new ones (Lazarević et al. 2003, Lazarevic et al. 2004, 2005). Beside our desire to reenter the European market another important prerequisite needs to be satisfied and that is introduction of HCCP system which will be obligatory from the next year and main condition for international trade with agricultural feedstuff products. Previous systems of control of veterinary-sanitary conditions were directed towards final product. HCCP system is different in a way that control is carried out in all phases of production process and sale/trade of product.

Previous period is characterized by:

- Absence of adequate systematic measures affecting the economical (in)security or primary agricultural producers of livestock for slaughtering. Without it, as well as without secured placement of product on the market, there will be no high and stable livestock production;

- Bad and inadequate organization of purchasing of livestock products from primary producers and directed towards the processing industry and the market;

- Consequence of modest/minor purchasing is poor utilization of capacities of slaughter industry. Low level of utilization of capacities is not economically justified since production costs per product unit are very high and leading to high production cost and high price of the product on the market. Also, slaughter industry, because of the chronical current non liquidity wasn't in position to pay off immediately primary producers based on supplied livestock for slaughtering but managed to do so with shorter or longer delay ( 15 to 60 days);

- Absence of functionality of protected - guaranteed prices in livestock production. Guaranteed prices often couldn't cover the basic costs of the production and loss was realized. It is necessary to stimulate this production with adequate measures and to stimulate export. In this way our country could find it self in equal position with other countries on the international market, in other words our products would be in a position to compete with large world exporters (Becker 1996, Đorović 1996).

- Disparities of prices are present permanently in agriculture in general and in livestock production. It is obvious that price of input, of agricultural consumption is moving with considerably higher intensity than purchasing price of livestock products. Consequence of this situation is diminished accumulative and reproduction ability of producers. Also lack of motivation of producers to be engaged in serious and market oriented production is one of the consequences. Due to bad conditions in regard to economical operation producers are forced to produce only for their own needs.

- Unfavourable credit - monetary policy in livestock production. Because of the lack of financial means agro-industrial firms and family households are not able to financially follow through the entire livestock production cycle. High interest rates in agriculture, which have extremely destimulating effect, have caused the situation in which economical subjects were not able to economically justify financial means for this production.

- Decrease in demand for livestock products is apparent. Namely, tendency of decrease in consumption of all kinds of meat, except poultry meat, is registered. This is caused by low income of consumers and their low purchasing power. A substitution in consumption is obvious, share of consumption of cheaper, poultry meat is increasing compared to consumption of more expensive beef and mutton (lamb meat). Also, consumption of cheese and majority of dairy products is decreasing. Without adequate demand there can be no increase in livestock production.

- Export of livestock products is absolutely unsatisfactory. In recent years, after the sanctions imposed on our country have been lifted, export showed no recovery. In the period from 1996 to 1999 export of livestock was 10 million dollars which is unsatisfactory. Even more, the negative balance of foreign trade of mentioned products in amount of over 12 million dollars is recorded. 
Livestock production has entered the year 2005 with all unsolved problems of recent years: unfavourable trends in regard to number of livestock, production of meat, milk and eggs, unused capacities and especially export of livestock and livestock products. Basis for further reproduction is especially endangered. Increase of prices and of quality of protein feeds, soy bean meal and fish meal as well as veterinary medications are making this already imperiled production even more difficult.

Condition of livestock production and the level of realized production can be presented through official statistical data.

Table 1. Number of cattle (in 000 of heads)

\begin{tabular}{|l|l|l|l|l|}
\hline Year & Cattle & Index & Cows and gestating heifers & Index \\
\hline 1985 & 2,026 & & 1,241 & \\
\hline 1996 & 1.335 & 100 & 1,111 & 100 \\
\hline 1997 & 1,318 & 98,7 & 1,087 & 97,8 \\
\hline 1998 & 1,280 & 95,8 & 1,048 & 94,3 \\
\hline 1999 & 1,283 & 96,1 & 1,051 & 94,5 \\
\hline 2000 & 1,246 & 93,3 & 1,024 & 92,1 \\
\hline 2001 & 1,162 & 87,0 & 946 & 85,1 \\
\hline 2002 & 1,128 & 84,4 & 913 & 82,1 \\
\hline 2003 & 1,112 & 83,2 & 897 & 80,7 \\
\hline 2004 & 1,102 & 82,5 & 885 & 79,6 \\
\hline
\end{tabular}

Source of data RBS

Number of heads of cattle over the last ten years is showing tendency of decrease. In 2004 there were 1.102.000 heads of cattle or by $17,5 \%$ less than in 1996. Decrease of number of heads of cattle is apparent in public and private sector.

Alarming is decrease of number of cows and heifers. From 1996 to 2004 number of cows and pregnant heifers was reduced by $20,9 \%$.

Analyzed period is typical for all branches of livestock production, decrease of number of heads of livestock and poultry in private and public sector. Public sector, although with relatively small participation in total number of heads of livestock, is very important since it consists of market producers whose products are intended for the market. In this sector of production we can find heads of livestock with good production traits (milk yield and meat yield), which are result of long term selection work. Further decrease of number of heads of livestock in public sector could have negative effect on production results in private sector of livestock production.

Table 2. Production of meat

\begin{tabular}{|l|l|l|l|l|}
\hline Year & Total meat & Index & Beef & Index \\
\hline 1985. & 615 & & 156 & \\
\hline 1990. & 616 & 100 & 155 & 100 \\
\hline 1996. & 529 & 86 & 103 & 66 \\
\hline 1997. & 520 & 84 & 92 & 59 \\
\hline 1998. & 513 & 83 & 97 & 62 \\
\hline 1999. & 520 & 84 & 97 & 62 \\
\hline 2000. & 518 & 84 & 104 & 67 \\
\hline 2001. & 454 & 73 & 93 & 60 \\
\hline 2002. & 480 & 78 & 97 & 62 \\
\hline 2003. & 451 & 73 & 95 & 61 \\
\hline
\end{tabular}

Source of data: RBS

Total production of meat in 1990 was $616.000 \mathrm{t}$, and in $2003451.000 \mathrm{t}$, decrease of $27 \%$ is recorded. In this period total production of beef was reduced by $39 \%$, pork by $10 \%$, mutton by $34 \%$ and poultry meat by $48 \%$. 
Data on age category of slaughtered cattle indicate high share of calves in total number of slaughtered cattle and pigs. Decrease of total meat production is consequence of decrease in number of livestock and especially category of fattening young cattle. Even with this number of cattle higher production was possible if fattening cattle was slaughtered with higher average body mass. In fattening of cattle the highest amount of energy per kg of growth is used in the first fattening phase. Therefore, fattening should be prolonged until animals reach body mass of $600 \mathrm{~kg}$ in order to obtain higher quantities of meat.

\section{Breed structure}

Cattle with combined traits in type of domestic Spotted breed and Simmental breed (70\%), crosses in type of Domestic Spotted and cattle of Busha type (approx. 25\%) and approx. 5\% of dairy breed cattle are present in Serbia. Meat type cattle originate mainly from Domestic Spotted and Simmental cattle and their production results, especially of Domestic Spotted cattle, are unsatisfactory. They are fattened to low final body masses $(420-450 \mathrm{~kg}$ ) with prolonged fattening, data on meat yield (dressing percentage of approx. 54$57 \%$ ) and meat quality are also unsatisfactory.

Of total annual meat consumption $2 / 3$ is placed by private sector or used as natural consumption. In last 9 months supply of fresh meat has been satisfactory although the total production of meat has reduced.

According to data obtained by Republic Bureau of Statistics on delivered quantities of livestock and poultry, increase in the second quarter of 2004 of $6 \%$ for cattle, $4 \%$ for sheep and $45 \%$ for poultry was registered. This is encouraging since in the last 10 years there has been no recorded increase of slaughtering of livestock in slaughter houses.

Table 3. Import and export of live animals and animal products - mil.. USD -

\begin{tabular}{|c|c|c|c|c|c|c|c|c|}
\hline & \multicolumn{3}{|c|}{ Export } & \multicolumn{3}{|c|}{ Import } & \multicolumn{2}{|c|}{ Saldo } \\
\hline & 2003. & 2004. & index & 2003. & 2004. & index & 2003. & 2004. \\
\hline Total & $1.770,4$ & $2.154,0$ & 121,7 & $4.624,3$ & $6.696,2$ & 144,8 & $-2853,9$ & $-4.542,2$ \\
\hline Food and live animals & 345,0 & 308,4 & 89,4 & 299,2 & 407,7 & 136,3 & $+45,9$ & $-99,3$ \\
\hline -Live animals & 2,8 & 2,0 & 73,1 & 2,8 & 3,2 & 115,4 & 0,0 & $-1,2$ \\
\hline -Meat and meat products / & 10,6 & 12,7 & 119,1 & 6,8 & 9,4 & 137,2 & $+3,8$ & $+3,3$ \\
\hline
\end{tabular}

Source of data: RBS

Export balance in regard to meat and meat products in the period January - August 2004 was positive by 3,3 million dollars which is also encouraging, however it is still below objective possibilities. It is necessary to work on introduction of HCCP system in all potential export slaughterhouses, intensify negotiations with EU relating to registration of export slaughter houses and at the same time define measures for stimulation of export of these products and bring domestic producers closer to level of export subsidies enjoyed by producers in other countries so that they could compete with other producers on the world market.

\section{Programme of improvement}

All households which are engaged in serious cattle production should be organized as households for market oriented production of milk, households for market oriented production of fattening cattle and households for combined market oriented production of milk and fattening cattle for slaughtering (Lazarević et al. 2003, Miščević et al. 2005).

- Households for market oriented production of fattening cattle

Fattening of young cattle in our country is very important from the aspect of production for domestic needs and even more important for export to foreign markets. Tradition of fattening of young cattle by our farmers is already known, as well as quality of beef. Organized fattening of cattle in the first phase (period of approximately 10 years) should engage 7.000 farms/households with average 35 heads of young cattle in cycle This means that organized and planned fattening of young cattle would include 200.000 of heads. These households should be organized on land in private ownership with average over 8 ha of plough land and meadows. Fattening of young cattle in organized farms should be for already known buyer and majority is for the export (live animals or carcass sides). 
Breeding objective on specialized fattening farms should be directed towards improvement and unification of the quality of meat from more heads of cattle in such organization of fattening. Cattle would be fattened until final body mass of approx. $550 \mathrm{~kg}$ in average. For low land region final body mass should be $600 \mathrm{~kg}$ and for hilly-mountainous region $500 \mathrm{~kg}$. Duration of fattening in average would be 350 to 360 days, with daily gain of 1.100 to 1.300 grams or in average 1.200 grams. Slaughter yield of these heads of cattle should be between 58 and $60 \%$ and young cattle would have high quality meat corresponding to demand on domestic and foreign markets. According to breed structure cattle for fattening would mainly be of Simmental breed and crosses of $F_{1}$ generation obtained from crossing of Domestic Spotted and Simmental cattle of lower production traits with bulls of French meat breeds Charolais (for low land region) and Limousine (for hillymountainous region).

- Households for combined market oriented production of milk and fattening cattle for slaughtering Combined farms can successfully be organized in low land and hilly-mountainous regions where enough of livestock feed, fodder or concentrates, of adequate quality can be provided. Combined farms should be organized in households owning over 10 ha of plough land and meadows. In the first phase 5.000 of such farms should be organized with in average 15 to 20 cows - total of 65.000 to 90.000 female cattle or $10 \%$ of total number of cows and heifers in Serbia. On these farms production of milk and fattening of young cattle would be organized. This group of farmers would consist mainly of farmers from hilly-mountainous regions, therefore this form of cattle breeding will be in function of realization of economical effect per head and will reflect on increased interest of household members to be engaged in such production.

Breeding goal of farms organized for production of milk and meat is different and should be in more directions, such as: milk-calves, milk-young cattle and cow-calf. Mentioned orientations or production directions will mainly depend on the region (low land or hilly-mountainous regions), quantity and quality of land, processing capacity, etc. Farmers specialized in production direction milk-calves or milk-young cattle will sell milk to purchasing centers or dairy plants and calves or male young cattle, will remain on the farm until they reach final body mass of 480-550 kg. The best breeds for this breeding system on our farms and conditions are Simmental breed and Domestic Spotted cattle. Group of farmers (cow-calf system) would breed more cows - in average 30 cows. Calves for fattening would be delivered to the market with body mass of approx. 180-200 kg in average or would be fattened on the farm until final body mass of approx. 480-550 $\mathrm{kg}$. For this production direction crosses obtained from crossing of Domestic Spotted cattle with French fattening breeds Charolais and Limousine as well as others are best suited.

\title{
Conclusion
}

- It is necessary to provide sure and constant sources for credits intended for primary production, especially livestock production.

- In order to protect domestic livestock production it is necessary to prevent uncontrolled import of these products and introduce adequate level of protection.

- National strategy of development of livestock production should include organization of market oriented producers of milk and meat.

- Higher degree of liberalization in foreign trade exchange of livestock products will enable traders to have more space in negotiating export arrangements.

- Intensify negotiations with EU regarding registration of new export slaughter houses.

\section{ZNAČAJ PROIZVODNJE JUNEĆEG MESA U SRBIJI}

\author{
B. Miščević, S. Aleksić, S. Josipović, V. Pantelić, Dušica Ostojić
}

Rezime

U radu su prikazani problemi i značaj proizvodnje junećeg mesa u Srbiji, stanje u kome se trenutno nalazimo i mogućnostima za unapređenje. Ukazano je na značaj proizvodnje junećeg mesa sa aspekta domaćih potreba i mogunost izvoza na tržišta EU čime bi se privreda i zemlja u celini oslobodila nepotrebnog uvoza mesa sumnjivog kvaliteta, a život stanovništva podigao na jedan viši nivo. Intenzivnije korišćenje 
iskustava koje daju nauka i struka u oblasti govedarstva kao i razvoj novih metoda odgajivanja rešilo bi problem unapređenja proizvodnje mesa i mleka. Korišćenje saznanja razvijenih zemalja i dobrih odgajivačkih programa može u veoma kratkom vremenu dati pozitivne rezultate i sa puno uspeha ostvarivati planiranu godišnju peoizvodnju junećeg mesa koja je poslednjih godina na niskom nivou.

Ključne reči: goveda ,junad, meso, odgajivački program

\section{Literature}

1. AASS L. (1996): Variation in carcass and meat quality traits and their relations to growth in dual purpose cattle. Livestock prod. Science 46(1), 1-12.

2. BECKER K. (1996): Distribution channels and promotion in the EU-Lessons for Ceec firms. Marketing, 4, Beograd.

3. CHAUHAN V, HILL W (1986): Saesonal grouping in a heard year, season model od sires evaluation. Animal production, 43, 63-71.

4. DIKEMAN M.E. (1994): Genetics of meat quality. Proc. $5^{\text {th }}$ World Congress on Genetics Applied to Livestock Production, 19, 437-449.

5. ĐOROVIĆ M. (1996): Agromerketing u funkciji tržišta. Nova trgovina, 3-4

6. LAZAREVIĆ R., LAZAREVIĆ LJ, MIŠČEVIĆ B., M. PETROVIĆ, S. ALEKSIĆ (2001): Need for the Organization of Farmers Engaged in Livestock Production. $6^{\text {th }}$ International Symposium "Systems of Animal Breeding and Economicof Animal Production at the Beginning of the New Millenium", 2-5 October, Hotel "Jugoslavija", Yugoslavia. Biotechnology in Animal Husbandry 17(5-6), P. 9-15. Plenary invitation paper

7. LAZAREVIĆ R., MIŠČEVIĆ B., RISTIĆ M., LEVIĆ JOVANKA, SREDANOVIĆ SLAVICA (2005): Sadašnjost i budućnost stočarstva i proizvodnje hrane za životinje u Srbiji, Vrnjačka Banja.

8. MIŠČEVIĆ B. (2003): The study of project "Beef meat production", Biotechnology in Animal Husbandry, 19(1-2), p:75-83.

9. MISCEVIC B., LAZAREVIC R., S. ALEKSIC, M. M. PETROVIC, S. JOSIPOVIC (2000): Increasing Meat Quality of Domestic Cattle by Using French Beef Breeds, $9^{\text {th }}$ Animal Science Congress of the Asian-Australasian Association of Animal Production Societies in conjunction with the Twenty-third Biennial Conference of the Australian Society of Animal Production, 122-127, 2-7 July, Sydney, Australia. R-72

10. MIŠČEVIĆ B., ALEKSIĆ S., R. LAZAREVIĆ, M. PETROVIĆ, S. JOSIPOVIĆ, DUŠICA OSTOJIĆ (2003): Beef improvement using new cattle genotypes, II Symposium of livestock production with international participation, Ohrid-Macedonia, June 18-21.

11. MIŠČEVIĆ B., ALEKSIĆ S., PETROVIĆ M., R. LAZAREVIĆ, S. JOSIPOVIĆ, TATJANA SMILJAKOVIĆ, DUŠICA TOMAŠEVIĆ, GORDANA MARINKOV, DUŠICA OSTOJIĆ (2003): Efect of genotype on major traits of carcass quality of young bulls, 7th International Symposium »Modern Trends in Livestock Production«, Belgrade, September 30th - October 3rd. Biotechnology in Animal Husbandry, Vol 19, 5-6, 35-41.

12. MIŠČEVIĆ B., LAZAREVIĆ R., PETROVIĆ M., ALEKSIĆ S., JOSIPOVIĆ S. (2005): The influence of different genotypes of bull calves on the quality of beef meat. 40. Croatian Symposium on Agriculture, Opatija 15-18 Februar. Zbornik radova 591-592.

13. MISCEVIC B. (2004): The influence of nutrition on the meat quality of cattle.

14. ZOOTEC 2004, $\mathrm{VI}^{\text {th }}$ International Animal Science Meeting 28th -31st May, Brasilia - DF - Brazil. Plenary invitation paper. Published on ZOOTEC official CD under Chapter: Palestras, Tema: Bovinocultura de corte

** Statistički godišnjak Republike Srbije, 2004

** Statistički godišnjak Republike Srbije, 2002

** Statistički godišnjak Republike Srbije, 2000 